\title{
Genealogical Mapping of Dalit and Historical Heroes
}

\author{
Dr. Amandeep (Assistant Prof in English)
}

DES.MDRC Punjab University Chandigarh

\begin{abstract}
History is a subject of perpetual construction and reconstruction, denial and acceptance, addition, deletion and revision. But its capacity in changing or influencing the attitudinal zone of mankind has been enormous. Subsequently, the dalit writers aware of this fact have made their maximum efforts on historical and mythological contents. The paper attempts to analyses archetypal dalit heroes such as Eklavya, Shambook, Angulimal, Karan, Ambedkar and others. It also discusses one of the most significant dalit historical characters Jhalkari Bai, a low caste warrior, guarding the main gate at the fort of Rani Lakshmibai at Jhansi. it shows how these characters are subverting the over-arching brahmincal intent of the so-called grand narratives. From their life it reveals that they should not learn Sanskrit or read the Vedas, lest by doing so, they become aware of their oppression. But since they did not live mutely according to prescription, provision for serious punishment was made for any breach of the injunctions been done. The history written by these writers is trusted by the recipients. It is a vehicle of emancipation. Dalit poets of 1990s add a new-rigour into the process of re-writing. The old heroes are re-written with newer significance. These characters are symbol of sacrifice, dedication and chivalry. History writing of these characters of dalit community is the greatest demand of today's time. In this way the historicity of dalit experience is conveyed through the allusive nature of Dalit writing, its strategy of liberating certain figures of history and myth from mainstream literature and using them to connect the present with the past.
\end{abstract}

Keywords: reconstruction, archetypal, subverting, oppression, emancipation, historicity, mainstream.

\section{PAPER}

The inequality generated by the caste system is a recurring theme in Indian literature, to which almost all dalit writers have responded seriously. The hegemonic caste structure that emerged in the early phases of Indian civilization continued with almost similar rhythm till the advent of British rule in India, sidelining and suppressing the iconoclastic messages of Buddhism and the Bhakti movement. Further, history took a dramatic turn when spiritual leaders from non-Brahminical communities were born. Kabir, Ravidas, Sen, Peepa, Rajjab did not belong to the Brahminical mode of religion, and they, by articulating their messages through folk languages, inspired many writers to create public opinion which became more and more widespread with the passage of time.Shudras ${ }^{1}$ and untouchables were to be severely punished for violating the ban according to the Brahminical texts. Over the centuries, the monopoly over knowledge that Brahmin men had was not merely evident in the area of ritual or religious knowledge, but also in the field of secular knowledge. The growing monopolization of knowledge by the Brahmins may have met with some resistance like those as occasional examples of those who did not conform to the codes and sought to gain knowledge or skills from which they had been barred such as Shambuka, who practiced austerities normally reserved by Brahmins, or Ekalaya, who acquired skills in archery, a privilege of the Kshatriyas, met with severe punishment. if finally only the brahminical view of the caste system has prevailed and has now become canonical in sociological theories of caste system, it is not unrelated to the Brahmins control over knowledge and through that to hegemonic forms of representation. But how this monopoly could be broken Tapan Basu says in this regard: it is because of the traditional exclusion from learning that Dalit intellectuals like Phule ${ }^{2}$ and Ambedkar have placed such importance on education as a weapon to be used in the resistance to Brahminism.( qtd in Tapan Basu, 203). Limbale a critic suggests that each dalit person's life partakes of the lives of all dalits. He argues: Dalit poets use a similar strategy when they recuperate mythic figures such as Shambuka, Eklavya, Ravana and Shurpanaka from Hindu religious literature, and use them in portraying contemporary dalit experience. (Limbale12). 


\section{Dr. Amandeep}

Before proceeding to discuss the emergence of contemporary dalit literature, it will not be out of order to have a glimpse of the level of deprivation suffered by these communities. They were forced to stay away from the historical mainstream, peripheral as they were, deprived of access to education and surrounded by terror. They were not only forced to stay away from history but also from any kind of leisure which is such a critical source in the creation of the culture of a community. The very nature of their jobs and social functions that they were coerced to perform prohibited them from owning and developing any cultural compartment for themselves or their community. They were not allowed to carry or own any weapon, even for self-defense, as such; the idea of social assertion never arose in them. They drew water from a separate well, and cremate their dead in a separate place. Orality was their only possession, or medium of communication of their anxieties, tribulations, deprivations, and anguish. They did not even have their religion to console themselves and, in such an alienated state, they feared even to entertain the idea of expression of their woes in the world after death; for it were their evil actions in their previous life that had placed them in such a precarious social position and any question pertaining to their existence would be considered to be violative of the divine design. The print medium was used by dalits not only for exclusive publication of newspapers, journals, and magazines but also for the publication of booklets containing history as they discovered or invented it, and also biographies of actors in history, who according to them had not been provided a respectful place. Through the print medium they now started subverting the entire Brahminical epistemic, from the Vedas and the Puranas to modern writings. Their desire to awaken from the slumber of the past necessitated dalit intellectuals to capture the present by exposing the 'misdeeds' of the elites, and construct a 'new consciousness' that paves the way for them to assert their demand for social respect from which they had remained deprived since centuries.

By mentioning the ongoing dalit discussions on history this does not mean that the movement is revivalist in nature, or that the present is missing, but rather, that it is an attempt to reconstruct the past on the basis of challenges posed by the present. Some important challenges have emerged from the demand for a space in society by communities which were hitherto neglected, degraded, and marginalized.

They attempt to debate historical myths, which as practiced in daily life, keep on suppressing them and their search for self-identity. This history claims to be different from previous histories, to be 'dalit'; yet it never draws on Marxism or any alternative historical paradigm. This history is largely dominated by the development of historical concepts in the social struggle. Its language, crafts, and forms are not directed by modes of the English language but are largely influenced by easily comprehensible Hindi and local folk dialects. It is a history which centers on heroes and their heroic acts. It is a history carved out of faces. In its writing the question of language is taken seriously because the selection of language means selection of a world that speaks that language. History, beginning with these grievances is, in fact, popular history. It is neither academic history nor has it any in-depth discussion. But it is their firm belief that dalits were never provided a proper status in Indian historiography. Also, the authors believe that till now Indian history is mostly written by Brahmin historians so they have not attained the status which is due to them. Thus, history written by the dalits can be called 'dalit popular history'. From this history they derive the confidence and the right to assert their humanity. In this sense the central purpose of this literature is to enable the development of new consciousness and identity among dalits. The discussion in the following stories attempt to give a history that is outside the parameters of history as defined till now. The present social position of the dalits which is marked by the will to capture power and use it for identity assertion, makes them, to their minds, architects of an alternative culture in which they can re-gain what has been snatched from them in the past.It is a history of the dalits by the dalits. It is a vehicle of emancipation. Its parlance is not patterned in categories and concepts intelligible to only the highly privileged in the dalit community.

For example, in Mool Vansa Katha, authored by G.P. Prashant, the character of Ram and other epical personalities is pushed forward to the Buddhist period, and Shambook is depicted as a Buddhist who refused to submit to Brahminical hegemony. Ram, in connivance with Itter Brahmin seers, kills Shambook when Ram confronts Shambook, they say:

It appears that the foreign blood, i.e., the blood of the conquerors is still boiling. They want to keep their language and blood relationship separate. Therefore, these opponents are writing everything in Sanskrit, which is not the mother tongue of the original inhabitants of the land. Who knows as to what 
they would write. And this would be ridiculous and tyrannous to the culture and people of the land. That is why Lord Buddha had asked to speak and write in the language of the common people i.e. (Pali) so that each of them are able to understand. Oh Ram! We have attachment to our culture, language and motherland. You should also develop the same. (Misra, 33).In fact, this narrative sees the beginning of the history of dalit assertion with the rise in Buddhism. With the use of local idioms Sanskrit is dubbed as the language of the ruling class. Ram's character is depicted in the context of development of Buddhism, its social impact and the reaction against it by the ruling castes. Much of the ancient history of India has been made mythology. It was done deliberately. Vizia Bharati wrote: Ramayana tells as clearly how Rama Killed Rakshaas to protect sages and yajnas and how the Rakshasa women were insulted by Rama who belonged to higher caste. (Bharati, 96)

In the story, Angulimal's notorious life is shown to be a conspiracy of a Brahmin couple, named Manibhadra and Shailendri. Shailendri, the wife of the Brahmin saint and teacher Manibhadra, is shown attempting to seduce Manvak (name of Angulimal before he becam4e a murderer) to which Manvak does not respond. Shailendri, infuriated over the failure of her designs surreptitiously concocts a story against Manvak and subsequently he is ordered by his righteousness. It is finally Lord Buddha and his disciples who teach him the true lessons of spiritual elevation. Dialogues in the drama are affirmations and negations of a particular standpoint and through this chain, a conclusion is reached. In this drama, Angulimal is the victim of the conspiracy of a Brahmin seer's wife. The narrative reveals the hollowness of morality in the ashramas of seers which is claimed to have functioned exclusively for spiritual elevation. This ashrama culture is contrasted with the Buddhist way of propagation of its religion and the persuasive path of correcting the deviants. Also, a contrast between Buddhist philosophy of equality and Brahminical theory of inequality is discussed in the form of dialogues.

Of the most significant dalit historical characters that are retrieved from the obscurity of the elitist nationalist discourse, Jhalkari Bai, a low-caste warrior, guarding the main gate at the fort of Rani Lakshmibai at Jhansi, receives repeated attention from dalit biographers and poets. In his poem, 'Virangana Jhalkari Bai', Rameshchandra Changosiya projects the dalit heroine almost on the same pedestal on which Rani Jhansi is often placed:

\author{
Surrounded as Maharani was \\ By the English \\ Jhalkari plunged in \\ for the sake of Rani and Jhansi \\ blazing as she was \\ in the form of fierce war-goddess- \\ that destroyer. (Akshaya, 303)
}

Brave Jhalkari (friend of Rani Laxmibai) was born in the year AD 1830 in the city of Jhansi. She belonged to the Kori community. Her gotra was Ladia. From her very childhood Jhalkari was playful, clever, and competent. Besides being a warrior, she was also obstinate. The fear in her disappeared on hearing the stories of chivalry from her father. She could never be dominated due to love and affection that she acquired from him. But she could not spend much time in games and sports as her father married her to Puran at an early age and, thereafter, she started living in her in-law's house. That Jhalkari was fearless and chivalrous has been confirmed by many authors. She was physically stout with fair complexion, large eyes and predominant nose. She was of a normal height. Her features were such that resembled the Rani. The only conspicuous difference was between the complexions of the two. Unlike Jhalkari, Rani had a highly fair complexion. The face of Jhalkari exhibited a kind of courage which appeared to be trickling down. it is true the Jhalkari was a beautiful woman with a well-built physique and smiling face. This fact is confirmed by the fact that when Jhalkari went to Rose dressed like a queen, he was confused. According to Varma, Rose said 'How handsome though dark and terrible'. From this it can be understood that her face was beautiful and from its aura, the enemies used to feel frightened. After her marriage with Puran, she started living as a housewife. Rising early in the morning, she would work on grindstone for flour and carry water to her house. She never attempted to escape from labour. Besides completing her household duties, she would also assist her husband in his occupational activities. Not only her husband but her in-laws also were satisfied and happy with her work. Although Jhalkari had no education, she had good understanding 
and discretion. She was adept in Bundelkhandi language. She was always true to her words and had a great regard for elders and saints. She had great respect for her neighbor Ganesh Baba who was always a source of inspiration to her. Pride never touched her, and self-respect never left her. She always remained true to her words. (P-136).

The great Hindu epics are seen quite differently from the Dalit viewpoint. The Mahabharata calls up not an image of heroism and performance of duty but the figures of Karna, the illegitimate son of Kunti, who was scorned by his Pandava brothers for his unknown parentage, and Eklavya, the low born, who cut off his thumb at the command of the guru he had followed afar, lest he might triumph over the guru's favorite, Arjuna, in archery. The Ramayana evokes the image of Shambuk, who was killed because he heard the Vedas, not the models of the perfect king Rama and the perfect wife, Sita. Eklavya and Shambuk as archetypal symbols of suffering appear in dozens of poems, though these references to minor epic characters are often tucked in the poetry without explanation, as in Waman Nimbalkar's "Kavita" (poem) which ends with a reference to the Buddha through the use of one of his names, Tathagatha, and to Eklavya as an oath of resolve.

Tryambak Sapkale also uses the image of Eklavya as strength:

$$
\begin{gathered}
\text { Round earth, } \\
\text { Steel oar } \\
\text { in my hand } \\
\text { but no oarlock? } \\
\text { O you ideal disciple } \\
\text { Eklavya! } \\
\text { Give me } \\
\text { Your slashed finger } \\
\text { For support. }
\end{gathered}
$$

(Zelliot, P-284)

This sentiment has been echoed and re-echoed in different languages throughout that century. Though Eknath came from Brahmin background but he had projected his glowing personality on a great cultural tradition and given an unforgettable utterance to its great ideals of self-realization, spiritual order and brotherhood of man. Eknath's abhangas ${ }^{3}$ are finest hymns of divine love, the most melodious expositions of the realization of God and precepts to humanity that have been set to music and sung all over the land. These 'Kirtans' ${ }^{4}$ like those of his predecessor Namdev have become an important part of the great musical heritage and they are cherished even in the present times. He was essentially a poet of the common man to whose spiritual welfare he dedicated his life and his language and simple diction that could readily evoke a response from his unlettered audience. Tryambak Sapkale writes how Angulimal was crawling and yelling for life, he hoping to meet some saint like Eknath and says:

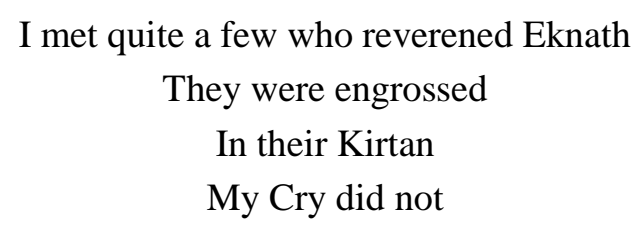

Enter their hearts ( Zelliot, 295)

Mulk Raj Anand rightly says:

The Process of poetry arising out of cry can be felt in most Dalit Poems, because in these utterances protest seems to come from the insulted and the injured, who have laboured for generation for the supers, their hands with dirty work. (Anand, xi).The forty- seven bharud spoken as a Mahar represent the Mahar duties as metaphors, as in: 'I sweep the four Vedas, I collect the rubbish of the six shastras, I gather together all the purans, I bring this to the streets of the Saints'. (Punekar, 261).

Eknath was the very picture and voice of humility. Though well versed in Marathi, Sanskrit, Arabic and Persian, Eknath never showed off his knowledge and scholarship. But asserting that Marathi was in no way inferior to Sanskrit, he expressed his highest thoughts in the language which was easily intelligible to the masses (Shridhar, 22). Eknath raised his stentorian voice to denounce caste distinctions, which had been the bane of society of his time, proclaiming that men could become one 
with God through devotion to Him and to humanity, and dwell in his world as instruments of the Divine. Eknath expostulated that the true purpose of man's spiritual endeavour was not to seek liberation by escaping from the world of mortals but to live in it knowing it to be divinely informed. Time and again he reminded the enlightened of their duty to the whole of humanity and the need to share their transcendental joy and knowledge with the unenlightened. This remind us Kabir ${ }^{5}$ who condemned the Brahmins. In rejecting the ceremonial practices of Hinduism and teaching his own doctrines, he was running counter to their prestige and influence, and naturally incurred their displeasure. There are many references to this in Kabir's verses. They seem constantly to have taunted him with his low caste; but Kabir reproaches them on the other hand with their ignorance of spiritual truth and failure to show the path of salvation. Thus he speaks:

Thou art a Brahman, I am a weaver of Benares; how can I be a match for thee?

By repeating the name of God I have been saved; while thou,

O pandit, shall be lost by trusting to the Vedas.

Or again:

Pandits have gone astray reading and studying the Vedas; they

Do not know the secret of their own selves...

Go and ask them who has thus found salvation;

If touched by another you wash your body;

But tell me, who is meaner than you? (Keay, 41)

However, by denouncing Hindu religious rites and practices which he thought were useless and not meaningful for spiritual progress, and thus unnecessary for realizing God, Kabir was not satisfied. He then directed the fury of his criticism against the Brahmans, the priest class which, according to Kabir, was responsible for misleading the people by encouraging them to practice all those superstitious practices and ceremonies in the name of religion. There are passages in which Kabir expressed his view to the effect that the Brahmans were cheaters of the people whom they deceived by posing as the pioneers and guardians of religion. There are many references to this in Kabir's verses. They seem constantly to have taunted him with his low caste, but Kabir reproaches them in return for their ignorance of the spiritual truth and their failure to show the path of salvation. Thus he says:

\author{
Why shouldst thou, O Brahman, forget Him \\ from whose mouth the Veds and the Gayatri issued? \\ Why shouldst not thou, O Pandit, utter the name \\ of God, whose feet every one toucheth? \\ O my Brahman, why not repeat God's name? \\ If thou utter not His name, O Pandit, \\ thou shalt be cast into hell. (Muhammad, 276)
}

It was B. R. Ambedkar, the prime architect of Indian constitution, the first graduate from the untouchable mahar community ${ }^{6}$ who made significant contributions to the anti-caste movement. An untouchable himself, Ambedkar championed the cause of the 'broken men' as he terms the Indian untouchables, and fought relentlessly throughout his life to ensure equality, social justice, self-respect and freedom for them. Ambedkar stood for the social liberation, economic emancipation and political advancement of the downtrodden-a task never undertaken by any high caste Hindu leader with so much vigour and force. And that is why, perhaps, Gandhi described him as "fierce and fearless" and Nehru acclaimed him as a "symbol of revolt against all the oppressing features of Hindu society." Ambedkar made it ample clear that the root cause of dalit oppression was the upper-caste monopoly over power and knowledge and in his vision the liberation of dalits was in their own hands.( Basu, Introduction,17). Ambedkar worked hard for a new constitutional order based on equality and social justice. Ironically, however, his dream has not materialized even after more than five decades of the working of the Constitution. The various kinds of torture perpetrated today on the Dalits are its testimonials. Dismayed and frustrated with this negative attitude, Ambedkar, towards the end of his life, rejected Hinduism and embraced Buddhism. As we have seen earlier, Buddhism advocates a casteless and classless society as against the Hindu society which is based on grades inequality. Buddha's opposition to human exploitation is, perhaps, the main reason for which Ambedkar finds in Buddhism an alternative. (Kumar, P-142) 


\section{Dr. Amandeep}

In dalit poetry of the post-1990s, Ambedkar receives singular attention and he is projected as a demigod across regions and languages. It is interesting to observe that while in mainstream politics as well as in literature, Gandhi's myth of mahatma undergoes a very uncharitable, if not hostile, dismantling; in dalit-domain, Ambedkar, after momentarily losing ground to the Panthers, not only regains ground, he stands resurrected literally as a Christ reborn. The post-Ambedkarite phase of dalit poetics is more a confirmation and continuation of Ambedkarite poetics than its negation or critical rejection (Kumar, 287) Not only does Ambedkar become the poetic subject, he is transformed into a poet as well. Kanwal Bharati, a leading Hindi dalit poet, in a daring experiment, re-writes Ambedkar's prosemessages into poetic form to assert the underlying poetic prowess of the scholar-politician. The appropriation of Ambedkar into the very community of poets suggests two things-one, in dalit discourse there is never a gap between poetry and politics, and two, dalit aesthetics is dissimilar, its lyricism lies in its experience of exclusion and not as much in sophisticated craft and diction ( Limbale, P-288).

Ambedkar emerges as a potential new Gorakh. He is indeed seen in the lineage of great Indian spiritualists. In his title poem, 'Jai Bharat, Jai Bhim', Iqbal Gharu, for instance, places Ambedkar in the lineage of great spiritualists- 'Mahatama Buddha, divine Nanak, Dashmesh Guru, bhakta Kabir, Tulsi Das, and Bhim Rao' that India has produced (Akshaya, 289). The poets are aware of the new debates of historiography and politics of representation and the play of power in the so-called objective accounts of the past. A woman poet, Kumari Archana Verma, has the same level of admiration for Jhalkari Bai, but she also brings in the fact of her being widowed in the battlefield: 'Lost husband, she remained unnerved, fought hard in the battle/though manuvad is discriminated/an untouchable as she was' (303).Dr. Ambedkar was a writer associated with the dalit anguish and the movement for dalit liberation.

Dismayed and frustrated with this negative attitude, Ambedkar towards the end of his life, rejected Hinduism and embraced Buddhism. As we have seen earlier, Buddhism advocates a casteless and classless society as against the Hindu society which is based on grades inequality. Buddha's opposition to human exploitation is, perhaps, the main reason for which Ambedkar finds in Buddhism an alternative.

Therefore, the language in his writings concerning dalit identity and the forms of words which he has selected for expressing the woes of the dalit shake the human mind. And this is poetry, which is available throughout his writings related to the dalit issues. Here is a 'petic excerpt' from Ambedkar's Hindu Dharam (Hindu Religion) poem:

Of all the religions

Hinduism is most distinctive and unusual

It has placed the untouchables in the category of inhuman.

Hindus have been made inhuman

And there is no way to escape

From the system of relationship

Between inhuman and unhumans (qtd in Misra, 232)

Dr Ambedkar revolutionary ideas stirred towards revolutionary actions of all the dalits and gave them a new energy. He appears repeatedly, as person and as emblem in dalit literature.

\section{CONCLuSiON}

The dalits have succeeded in developing their own political culture and historical identity through reconstructing the past and at this juncture, the shudras and the Atishudra acquired, for the first time, heroic and sub- heroic status in Indian literature. Hindu Philosophical concepts such as fate also weaken class- consciousness. As Dangle writes: Hindu writers find it difficult to cope with the Ambedkarite hero who is a rebel with a scientific and rationalist attitude; on the other hand, heoes like Karna and Ekalavya are consistent with the cultural and mythical value- structure which they have internalized.( Dangle, 285). Heroes such as Karna and Ekalavya are reconciled to the varna system; they are courageous, but because they have been denied the place they deserved in the system, they view life only in terms of suffering; these heroes, because they have been rejected by religion, become simply toys in the hands of fate. Such heroes offer a lot of suffering; high drama, a good deal of conflict and intense aesthetic pleasure; they easily offer an opportunity to express a fatalistic ideology, 
which is nothing but taking refuge in religion in order to adjust to the demands of a class-society. Such a hero tries to persuade the reader to believe that life is nothing but suffering, and the reader is so persuaded. The portrayal of such a hero offers the reader the pleasure of revisiting his own experience. Such works of art manifest nothing but Hindu mythical values and consciousness. However modernist its appearance may be, literature which conforms to such ideals is reactionary. The way in which Dalit writers evoke their own past, the references to "Babasaheb" Ambedkar and to Buddhism, the use of recent events, are the most interesting themes at least as far as the historian in me is concerned. Although most of the poets are educated, many are city-dwellers, and some have entered at least the lower reaches of middle-class comfort, the Mahar past is not far from even the young generation. The narratives in the form of small booklets have played a highly significant role in the formation of political culture. . So in these way dalit writers rejects the dominant cultural tradition, and the movement for dalit identity points towards the multiple discourses of tradition

\section{GLOSSARY}

[1] The lowest of the four varnas; traditionally those who served the three higher varnas of 'Brahmins, Kshatriya and Vaishya'. In the south and to a lesser extent in Maharashtra, all nonBrahmins are considered to be shudras or a group below shudras, those without varna or untouchables.

[2] Mahatma Jotirao Phule(1827-1890).

[3] A form of spiritual poetry in Marathi

[4] A sermon interspersed with devotional singing, also congregational singing.

[5] A kirtankar is an acknowledge leader of the Kirtan.

[6] A $14^{\text {th }}$ century Hindi poet, who believed in mysticism and wrote against the negative concepts of Hinduism. Dalits regard him as a one of their own.

[7] Mahar group is one of the major sections of the untouchables, normally believed to be the original inhabitants of Maharashtra.

\section{REFERENCES}

[1] Anand, Mulk Raj and Eleanor Zelliot. Eds. An Anthology of Dalit Literature. New Delhi: Gyan Publishing House, 1992.

[2] Basu, Swaraj. Readings on Dalit Identity: History, Literature and Religion. Orient Blackswan, 2016.

[3] Basu Tapan, Das. Translating Caste. Eds. New Delhi: Katha, 2002.

[4] Bharati Vizia, Hindu Epics: Portrayal of Dalit women in Jogdand P.G, Dalit Women in India: Issues and Perspectives. New Delhi: Gyan Publishing, 1995.

[5] Headayetullah Muhammad, kabir: The Apostle of Hindu-Muslim unity. New Delhi: Motilal Banarsidass, 1977.

[6] Kulkarni, Shridhar, Saint Eknath.. A silver jubilee pub, 1985. A silver jubilee pub, 1985.

[7] Kumar Akshaya. Poetry, Politics and Culture, New Delhi: Routledge, 2009.

[8] Keay, F.E. Kabir and his followers. New Delhi: MittL PUB, 1931

[9] Kumar, Raj, Dalit Personal Narratives: Reading caste, Nation and Identity. Orient BlackSwan, 2010.

[10] Limbale. Towards Aesthetics of Dalit Literature: History, Controversies and Considerations. Trans. Alok Mukherji. Hyderabad: Orient Longman, 2004.Referred to in the text as Aesthetics

[11] Misra, A.R and Badri Narayan. Multiple Marginalities: An Anthology of Identified Dalit Writings. New Delhi: Manohar, 2004.

[12] Prasad, Jayashanka. Hindi Kavya mein Dalit Kavyadharna. Varanasi: Vishvavidyalay Prakashan, 1993.

[13] Zelliot, E., From Untouchable to Dalit: Essays on Ambedkar Movement. New Delhi: Manohar, 1992.

[14] -----. And Rohini Mokashi-Punekar. Untouchable Saints: An Indian Phenomenon. New Delhi: Manohar, 2005. 